Берест, Тетяна. «Концепт вода в метафоричному полі творів Назара Федорака». Лінгвостилістичні студіï, вип. 11, 2019, с. 15-23.

Berest, Tetiana. "Concept Water in the Metaphorical Field of Nazar Fedorak's Works". Linguostylistic Studies, iss. 11, 2019, pp. 15-23.

Удк 821.161.2'371+33

https://doi.org/10.29038/2413-0923-2019-11-15-23

\title{
КОНЦЕПТ ВОДА В МЕТАФОРИЧНОМУ ПОЛІ ТВОРІВ НАЗАРА ФЕДОРАКА
}

\author{
Тетяна Берест \\ Харківський гуманітарний університет «Народна українська академія», \\ Харків, Україна
}

У статті проаналізовано поле концепту ВОДА в поезії Назара Федорака. Визначено й описано найбільш продуктивні вербалізатори, окреслено семантичні сфери, що формують означений концепт, зафіксовано індивідуально-авторські елементи в наповненні концепту. Установлено переважання негативного емоційнооцінного забарвлення образів води, продуктивність співвіднесення їх з небезпекою, занепадом, загибеллю. Відзначено узуальні символічні елементи наповнення образу та індивідуально-авторські.

Ключові слова: концепт, контекст, конотація, ідіолект, мовна картина світу.

\section{CONCEPT WATER IN THE METAPHORICAL FIELD OF NAZAR FEDORAK'S WORKS \\ Tetiana Berest}

Kharkiv University of Humanities “People's Ukrainian Academy”, Kharkiv, Ukraine

The article analyzes the concept of water in the poetic works of Nazar Fedorak. The study has revealed and described the most efficient productive verbalizators, delineated semantic spheres that form the meanings of the concept, and documented unique author's personal elements in the content development of the concept. The case study of the poetic works elucidated a distinct predominance of the negative emotional and social background in the image of water, and its strong correlation with danger, degradation, and death. Both traditional symbolic elements of the image content and the author's individual elements are used in the image creation.

The concept of water is highly productive in the imagery system used by Nazar Fedorak. The frequency of this image usage in the poet's idiolect, revealed in the collections issued with an interval of 17 years, underpins this conclusion. The semantic potential of the image of water is obviously quite powerful, but when compared to the ethnolect imagery system, it is somewhat narrowed. The analysis of the concept in the works of Nazar Fedorak has identified some peculiarities in the reproduction of reality based on the metaphoric image of water. Most images of water are marked with a wailful emotional background. Most often, the poet refers to the concept, correlating it with troubles, anxiety, danger. The concept of water often conveys the meaning of transience of time, decline, death, destruction, and oblivion. Modeling the figurative meaning of water-element, the author emphasizes its

\footnotetext{
(C) Берест Т., Східноєвропейський національний університет імені Лесі Українки, 2019.
}

Це стаття відкритого доступу на умовах СC BY-NC 4.0 
primordiality, eternity, variability, and destructive nature. These images are traditional associations with water power, including autumn and winter landscapes. In addition, the poet links the meteorological realizations of the poetic image of water with the concepts of pairing and love, which are among symbolic meanings of water in the folklore. It is worth mentioning that due to the productivity of the anthropo-zoomorphic metaphors, primarily related to the phenomena of nature, the concept of water acquires the meanings of a creature, human, and animal. The study sheds light on the author's rethinking of water as a victory (a hint of the text "The Tale of Igor's Campaign") and water (snow) as lyrical hero (individual author's images).

Further research is suggested to determine the concept of water in the idiolects of contemporary authors representing the postmodern trend in the Ukrainian literature. world.

Key words: concept, context, connotation, individual style, linguistic picture of the

Вступ. Останнім часом серед лінгвістів досить актуальним є прагнення до інтеграційного розуміння мови як динамічної антропоцентричної системи. Такий підхід зумовив посилення уваги лінгвістів до когнітивних і лінгвокультурологічних аспектів їі дослідження. Мова не лише задовольняє потреби спілкування, а й «виступає сховищем інформації, накопиченої мовним колективом, який живе в певному екологічному середовищі, засвоює її при змінних, проте характерних саме для нього соціальних умовах, для його культурного й громадянського розвитку тощо (Телия 175). Інформація певним чином упорядковується, структурується в мові, утілюючись у мовну картину світу. На думку багатьох дослідників структуризація знань про світ акумулюється в певних концептах. Концепт $€$ складною динамічною структурою, що грунтується на понятті та включає етимологічний, історичний, соціокультурний, асоціативний, емотивний та інші важливі складники (Г. Степанов, І. Стернін, К. Воркачов, М. Кочерган, В. Жайворонок, А. Приходько).

Концепт ВОДА є одним із тих, що становлять підгрунтя мови й усієї картини світу, і належить до базових концептів. У міфологічному уявленні українців, як і багатьох інших народів, культ води посідає одне з найбільш важливих місць. Нам відомі дослідження концепту ВОДА в мовній картині світу на матеріалі фольклору (Венжинович; Макарець), давньоруської мови (Гришина), у структурі поетичної картини світу Т. Шевченка (Антонюк, і Прісовська), неокласиків (Мініськевич), М. Вінграновського (Мініч), на матеріалі російської мови (Галдин; Гришина). Що ж до творчості сучасних українських авторів-постмодерністів, зокрема поета Назара Федорака, то мова їх творів, часто сконцентрованих довкола наскрізної теми людини й етносу у всесвіті, не була ще предметом спеціального дослідження.

Незважаючи на пильне вивчення концептів та мовної картини світу в різних напрямках і різними способами, у цій царині на сьогодні $\epsilon$ й, на наше переконання, ще на досить тривалий проміжок часу залишиться досить багато дискусійних та маловивчених питань. Слід мати на увазі те, що «мовна картина світу показова когніолінгвістичним статусом, тим, 
наскільки адекватно в її окремому мовленнєвому фрагменті, який сприймається суб'єктивно, відображено об'єктивні моменти знання, історичного досвіду культури даного мовного етносу» (Галдин 5).

Кінець XX - початок XXI ст. в українській культурі ознаменовано розвитком постмодернізму. Загальна ірраціональна тенденція, відкидання класичних зразків, специфічні художні техніки осягнення й відтворення дійсності зумовили створення своєрідної поетичної мови, в основу якої покладено гру, перевтілення, синтез, символічність, переосмислення, тому цікавим $\epsilon$ дослідження динамічної структури концепту саме в постмодерному ідіолекті.

Означене вище $\epsilon$ підставою говорити про актуальність дослідження своєрідності мовної реалізації одного 3 ключових концептів мовної картини світу - ВОДА - в сучасних українських художніх творах, зокрема в ідіолекті Назара Федорака. Дослідження дозволить розширити й доповнити лексико-семантичне поле концепту.

Мета дослідження. Метою роботи $є$ описання поля концепту ВОДА в поетичних творах Назара Федорака. Ми ставимо завдання визначити й описати найбільш частотні вербалізатори концепту ВОДА, окреслити семантичні сфери, які формують означений концепт у досліджуваному ідіостилі та зафіксувати індивідуально-авторські елементи в наповненні концепту.

Матеріал і методи дослідження. Джерелом дослідження слугували поетичні тексти збірок Назара Федорака («Брудершафт із собою» (1997), «Світовий браслет» (2008), «Скляний очерет» / «Р[озкриваючи] К[риптоніми]» (2014), матеріал студій - понад 300 номінацій.

Для розв'язання завдань і досягнення поставленої мети використано метод суцільного добору матеріалу з поетичних збірок, синхроннодескриптивний метод роботи для інвентаризації відібраного матеріалу, метод підрахунків - з метою визначення найбільш продуктивних способів вербалізації концепту, дефініційний - для виявлення понятійного компонента концепту, структурно-семіотичний метод аналізу лексики, концептуальний - для моделювання й опису концепту в індивідуальній поетичній картині світу.

Результати дослідження та дискусія. У дослідженні спираємося на думку про польову структуру концепту, представлену ядром (базою) та периферією (інтерпретаційний шар) (Попова, і Стернін 58).

Семантичне ядро концепту ВОДА в сучасній українській картині світу складають їі фізичні та хімічні властивості, здатність утворювати водойми, лікувальні, очищувальні можливості (Словник 1: 716). Український симболарій пов'язує воду 3 багатьма традиціями, обрядами, що супроводжується великим спектром значень. Символ пов'язують із зародженням життя, у ряді випадків навіть поділяючи на «чоловічу» воду (дощ, сніг) та «жіночу» (земні води); із паруванням та родючістю, чистотою та чесністю, здоров'ям, порятунком, рухом та змінністю, 
небезпекою, перешкодами, завзятістю, з плинністю часу тощо (Войтович 83-86; Макарець).

Концепт ВОДА у творчості Назара Федорака один із найчастіше використовуваних і наділених значним семантичним потенціалом. Поряд із центральним елементом поля - вода - часто вживаними конкретизаторами-апелятивами концепту є море, ріка, океан; дощ, сніг; рідше трапляються вербалізатори роса, туман, хмари, серед пропріативів, залучених до оформлення концепту ВОДА - гідроніми Йордан, Дніпро, Дон, Полтва, Лох-Нес, Севан, Лета, Байкал. Їх використання, реалізовувана ними семантика та виконувані функції в більшості контекстів пов'язані 3 традиційними символічними значеннями (Йордан, Дніпро, Лета), часто є опорним елементом для алюзії (Лета, Дон).

Аналіз засвідчує, що номінатив вода в аналізованому ідіолекті нерегулярно актуалізує деякі основні елементи ядерної семантики. Зафіксовано незначну кількість контекстів, у яких метафоризація значення концептуально значимого компонента семантики 'рідина' призводить до розвитку додаткових символічних значень 'стихіяпершопочаток, основа' ( «А ми свою малесеньку планету / Крутили стрімко в космосі води...» (Федорак, Скляний 24); «Чи ти діва, чи вітер, чи мрія, / Чи душа світової води?» (Федорак, Світовий 49)); 'очищення' («...дай ия вода / затопить розгублену кров, що відболіла» (Федорак, Р[озкриваючи] 8); 'справжнє, природне' («Ти риба, якій поміняли воду на чай, / річку - на ліжко, луску - на шовкову піжаму» (Федорак, Брудершафт 11)); 'сталість', 'заведений порядок речей' («Хай пливуть каравани і гавкають пси. / Хай течуть разом з ними вспокоєні ріки - / Споконвік не здолати воді береги» (Федорак, Світовий 17); «На битий шлях, на питу воду / Усяк уже перехворів» (Федорак, Брудершафт 56); 'почуття' («I залюбки / досхочу плескає вода, - у ній, у ній, у ній... У ній / чиїх очей м'яка слюда / мене змиває?..» (Федорак, Брудершафт 30)). Квантово-механічні властивості води лягли в основу яскравого образу емоційної холодності, відстороненості 3 виразною негативною оцінністю: «Ростуть роти підземних переходів, / кути зубів, пратемрява горлянок; <...> скляна вода вкриває невідомість, / і пальці рук, мов кущики, над нею / гойдаються самотньо...» (Федорак, Скляний 9).

Значно частіше ініціальна назва поля аналізованого концепту реалізує периферійну семантику метафоричного поля - 'небезпека', 'загибель', 'занепад' та 'забуття'. Це цілком співвідносно зі специфікою постмодерного ліричного героя та особливостями його світобачення. За основу такого смислотворення беруться як ядерна ознака концепту ('стихія'), так і символічні його значення у світовій та українській культурі: маємо алюзії з давньоірландськими міфами та легендами, де автор вибудовує асоціації між отруєним вином, отрутою, що пролилася на місці загибелі персонажа та водою (Федорак, Брудершафт 76; Федорак, Світовий 82); в інших контекстах використано узуальні образи мертвої 
води (Федорак, Скляний 37), руйнівної (Федорак, Світовий 34). Поєднання значення 'руйнівна стихія' та 'змінність, непостійність' засвідчує такий ліричний фрагмент: «Помсто, помсто, ти з'їдаєш / Шукачів твоїх. Вода $\epsilon$ твій рідний знак: / То припливи, то відпливи, / Мовби доля нещаслива / сміється так...» (Федорак, Світовий 55). Образ тихої води в українській мовній картині світу пов'язується, 3 одного боку, 3 прихованою небезпекою, з іншого - зі стагнацією, занепадом. Саме останнє значення $\epsilon$ притаманним поетичному ідіолекту Назара Федорука: «Не відпливайте, кораблі, / не в'яньте, вересневі мрії!.. / Вже серед поля тихих вод / між мовчазними берегами / втирає очі рукавами / Високий Мандрівний народ...» (Федорак, Світовий 73). Виявлено також звичне для образу значення 'втрата', 'розлука' («Кордони перетворено на води» (Федорак, Світовий 67); «Між нами глибоких доріг океани, / сліди на воді... / Їх надовго не стане...» (Федорак, Брудершафт 50)), що реалізується, зокрема, і через фразеологічні одиниці («...Пустивши за водою ніжні пута» (Федорак, Брудершафт 73); «Я не можу уплисти за водою-водою...» (Федорак, Брудершафт 92)).

Щодо «позитивних» образів, вербалізованих назвою вода, то в аналізованих творах - це застосування традиційного символу парування в контексті, стилізованому під народну пісню: «...як сонще і тінь, як сніги $i$ вода, / з'єднається пара навік молода!.» (Федорак, Р[озкриваючи] 32); аналогічне образне значення має прикметник водний у поєднанні із символом життя шлях: «Хай у човні нам буде тепло й тісно, / Хай лєпрекони, ельфи й все таке / Пильнують наше судненя хитке, / Наш водний шлях $i$ щастя безколісне!» (Федорак, Скляний 52). Алюзія на міфи й давню літературу з образами дивів, роздоріжжя, бандури, дерев'яного звіра містить і оказіональне позначення перемоги через образ води в шоломах (Федорак, Брудершафт 22), що, на нашу думку, розширює семантичне поле лексеми вода в аналізованому ідіолекті.

Тематичну групу «водойми», що також належить до ядра номінативного семантичного поля ВОДА, у поезії Назара Федорака найбільш широко представлено назвами море, річка (ріка), рідко, переважно для позначення великого розміру застосовується образ океану. Утілюючись у лексемі море, аналізований концепт актуалізує насамперед ядерні для семантичного поля назви значення великого простору, далечі, на основі яких виникають додаткові смисли: море - 'час, далеке минуле' («Мені не сниться <...> Ні та зрадлива вперта колісниця, / Загублена в найдальшому з морів» (Федорак, Брудершафт 41); «Вийшов на берег - а море втекло! / Нема його: хвилі піску замість моря» (Федорак, Скляний 27)); море - 'незабутні події минулого' ( острови» (Федорак, Р[озкриваючи] 33); море - 'вічність, сталість' («Йому лишились небо й зорі, / птахи й вітри в височині / $i$ - вічністю між «так» $i$ «ні» - осіннє море неозоре...» (Федорак, Світовий 73). Значно рідше актуалізуються значення 'стихія води' («Коли один із них підняв над морем 
скелю, / Розжарену в огні, й у водну вверг оселю, / то закипів весь світ...» (Федорак, Світовий 50)) Більшість зі створюваних на основі поняття моря образів мають мінорне емоційне наповнення. Слід відзначити, що в ідіолекті Назара Федорака $\epsilon$ досить продуктивним спосіб передачі емоційного стану неспокою, тривожного очікування через образ моря: «Море то гладке, то люте, / Друзі - мовби і не люди: / зіниці - страх» (Федорак, Світовий 55); “І м морське рухоме тіло / До очей нам прикипіло...» (Федорак, Світовий 60). Рідше автор співвідносить цю водну стихію 3 позитивними емоційними проявами чи мріями, підгрунтям яких $\epsilon$ уявлення про вільну, неспокійну велику воду: «стелі бракує морської хвилі» (Федорак, Брудершафт 45); «Я марив морем у пустельних мурах. / Піщаним квітам бракувало зросту...» (Федорак, Скляний 27). Смислове наповнення море - 'смерть' в поетичному ідіолекті виникає на перехрещенні значень 'вічне, безсмертне' та 'стихія, що випробовує людину': “...у море кидає / нас по краплі життя...» (Федорак, Світовий 65); «...можна так і так / жити між людьми, / як писав поет - наглядач тюрми: і скарби, й сміття виносить / море у шторми» (Федорак, Світовий 77).

Ядро семантики назви ріка, ще одного продуктивного виразника концепту ВОДА в ідіостилі Назара Федорука, формують ядерні ознаки 'потік', 'тече', 'велика кількість чогось, що рухається' (Телия). Відштовхуючись від них, автор створює трагічні образи нерухомих рік, сухих рік як символу краху (ріка без крил (Федорак, Брудершафт 15); піщана ріка (Федорак, Скляний 8); якась ріка серед піску (Федорак, Скляний 41)) та образ протиприродності, порушення заведеного порядку («Зазвичай час перемагає хаос, / Але буває <... / Каміння постає проти ріки...» (Федорак, Світовий 86)). Денотативна ознака невпинного й незворотного руху, притаманна семантиці лексеми ріка послужила підгрунтям для семантичного наповнення ріка - 'плин часу', 'плин життя'. у таких моделях назва набуває переважно мінорного емоційно-оцінного забарвлення (про загибель трьох сотень воїнів: «Три сотні рік повернуто назад...» (Федорак, Брудершафт 70); «Фігурки мерехтять: то Сун, то Тан, / Навшпиньки човен по ріці ступає, / Сама ріка в поклоні пропливає...» (Федорак, Світовий 84)), іноді символ плинності доповнюється відтінком надії («Не квапся, часе <...> / Повільна річка хай зупинить води...» (Федорак, Скляний 14); "А онде люба річечка, / мов молодість, хлюпоче: / а мо', хоч невеличечка / весна вернуться схоче?» (Федорак, Скляний 23)).

Низка важливих для образу води смислів в індивідуальній поетичній картині світу Назара Федорука вербалізована через метеоназви дощ, сніг, рідко - гроза, роса. Іноді в такому вираженні концепт ВОДА актуалізує ядерні семи - 'природне явище', 'волога', 'зима', проте навіть такі вживання супроводжуються певними додатковими асоціаціями, бо в усякому поетичному слові закладено концептуальне й емоційно-оцінне значення, а поетичний твір $\epsilon$ складним, певним чином організованим смислом. Найбільш продуктивними смисловими наповненнями концепту, 
представленого через метеоназви $\epsilon$ такі, що співвідносяться 3 традиційними поетичними й символічними значеннями лексем дощ та сніг. ВОДА-дощ в аналізованих текстах найбільш часто пов'язана з міським пейзажем і реалізує смисли: 'парування, запліднення' («...не знаєм досі ти $i$ я / спинився хто під небом, / здійнявши лінії дахів / над нашими дощами» (Федорак, Брудершафт 62), «Зійшлися ми по-східному - в шатрі: / Озерний берег, дощ і мокрі сосни...» (Федорак, Скляний 24)); 'неприємні стани, події' («Незнаний писатель над площею Ринку / впустив між дощем голубину хустинку» (Федорак, Брудершафт 49); “Коли ще свіжа / опадала з неба / поміж дощами чиста голубінь...» (Федорак, Скляний 32)); 'розмивання, стирання' («...місце / вдалині / розмивається дощем» (Федорак, Р[озкриваючи] 10)); 'плин часу, помирання' («Руділи обладунки під дощами, / Хололи руки, пестячи мечі» (Федорак, Брудершафт 71)); 'сталість, незмінність' (супроводжується мінорним настроєм: «Iдуть самотні $i$ кулясті / Дощі з дощами пополам...» (Федорак, Брудершафт 87); «..за дощем приходить дощ...» (Федорак, Брудершафт 13)); 'жива / нежива вода' («Впала гроза - i відчули ми: / Змокнемо або воскреснем!» (Федорак, Світовий 40); «Падав люд із дощем, $i$ котились понуро...» (Федорак, Брудершафт 12). Оригінальність авторського бачення світу виявляється в образі дощів-людей. Для олюднення автор звертає увагу на частини тіла, елементи одягу, дії, притаманні людині, вчинки й здатність виявляти емоції (Федорак, Брудершафт 13). ВОДА-сніг в ідіолекті Назара Федорака $\epsilon$ незамінна при передачі важких емоційних станів, значень 'жаль', 'втрата' («...і снігу калюжка в чужім краю...» (Федорак, Світовий 14)), нерідко позначає випробування («B снігах мужніють криця $і$ чуття...» (Федорак, Світовий 83); «Заведений браслетом <...> у сніжну бурю...» (Федорак, Світовий 89)). Ознака кольору трансформується в значення 'світло' («...сніги світили путь» (Федорак, Брудершафт 25)) й далі - 'чистий папір', на якому «дерева пишуть вірші» (Федорак, Світовий 74). Враження плину часу автор створює через зіставлення снігу й часу («I сніг пролітає, $i$ час поруч з ним пролітає» (Федорак, Скляний 35)), через метонімічне позначення пір року («Безперервно: то зелень, то біль, / то трава, то сніги...» (Федорак, Скляний.29) та через персоніфікацію снігу («...вмирає сніг, як вірний пес в ногах...» (Федорак, Брудершафт 14). Персоніфікований образ снігу трапляється так само часто, як і відповідний образ дощу, i твориться переважно через приписування дій, властивих людині, та має негативні конотації. Семантика холоду, емоційного дискомфорту реалізується через об’єктивацію ліричного героя в образах снігу (Федорак, Брудершафт 89), «теплого Бога зі снігу й льоду» (Федорак, Брудершафт 53).

Маємо низку контекстів, у яких одночасно використовуються образи снігу й дощу, що частіше виражають метафоричні й символічні значення, притаманні лексемі дощ ('рідина': «Це не дощ - це на дереві сніг перший топиться, / це не листя - це в морі його острови...» (Федорак, Р[озкриваючи] 19) «Снігами лище херувим умиває» (Федорак, 
Брудершафт 60)) та вода ('беззмістовні повідомлення', 'багатослівні повідомлення': «Конверти зі снігом приходять, <... / Розкриєш - і слова не втямиш: розлита вода» (Федорак, Світовий 10)). У деяких випадках смисл сніг - 'вода', що спочатку формується завдяки контексту з елементами мокрий, сльози, тече, розходиться півколами, трансформується в значення 'пелюстки', актуалізуючи ознаку кольору й специфіку руху: «Розпадається на членики, / самогубцям шле привіт / сніг на вулиці коперника - ...шневий вітер з ...невих віт» (Федорак, Брудершафт 39).

Висновки та перспективи досліджень. Концепт ВОДА посідає значне місце в системі зображальних засобів, використовуваних Назаром Федораком, про що свідчить як частотність цього образу в ідіолекті, так і його продуктивність у різних збірках, виданих з інтервалом у 17 років. Семантичний потенціал образу $є$ досить значним, хоча, порівнюючи 3 полем концепту ВОДА в етнолекті, маємо відзначити певне його звуження.

Простежуємо певні особливості у відтворенні дійсності за допомогою аналізованого концепту у творчості Назара Федорака: більшість образів води позначено мінорним емоційним забарвленням. Найчастіше поет звертається до концепту ВОДА, співвідносячи його з неприємностями, тривогою, небезпекою, випробуваннями, часто виникають значення швидкоплинності часу, занепаду, загибелі, руйнування, забуття. Моделюючи образну паралель ВОДА-стихія, автор частіше підкреслює ії первинність, вічність, мінливість та руйнівний характер, традиційно пов'язує 3 водоймами, а також осінніми й зимовими пейзажами. Метеорологічні реалізації поетичного образу води поет пов'язує, крім зазначеного, із поняттями парування, кохання (одне із символічних значень води у народних творах). Слід також відзначити, що, завдяки продуктивності антропо- та зооморфічних метафор насамперед із назвами явищ природи, концепт ВОДА має смисли 'істота', 'особа', 'тварина'. Індивідуально-авторськими вважаємо переосмислення ВОДА - 'перемога' (натяк на текст «Слова про похід Ігоря») та ВОДА (сніг) - 'ліричний герой'.

Перспективи дослідження вбачаємо у ширшому вивченні концепту ВОДА в ідіолектах сучасних авторів.

\section{Список використаних джерел}

Федорак, Назар. Брудершафт із собою. Київ: Смолоскип, 1997.

Федорак, Назар. Світовий браслет. Київ: Факт, 2008.

Федорак, Назар. Скляний очерет / Р[озкриваючи] К[риптоніми]. Львів: ЛА «Піраміда», 2014.

\section{Sources}

Fedorak, Nazar. Brudershaft iz soboiu. Kyiv: Smoloskyp, 1997.

Fedorak, Nazar. Svitovyi braslet. Kyiv: Fakt, 2008.

Fedorak, Nazar. Sklianyi ocheret / R[ozkryvaiuchy] K[ryptonimy]. Lviv: LA “Piramida”, 2014. 


\section{Список використаної літератури}

Антонюк, Олена, і Прісовська, Галина. «Репрезентанти концепту вода у творах Т. Г. Шевченка». Одеський лінгвістичний вісник, вип. 3, 2014, с. 13-8.

Венжинович, Наталія. «Актуалізація концепту вода у фраземах російської та української мов: лінгвокультурологічний аспект». «Вода» в славянской фразеологии и паремиологии. Т. 1. Budapest: Tinta Könyvkiadó, 2013, c. 196-201.

Войтович, Володимир. Українська міфологія. Київ: Либідь, 2002.

Галдин, Евгений. Конщепт ВОДА как полевая структура и способы его выражения в русском языке: На материале поэтических текстов И. А. Бродского. Автореф. ...канд. филол. наук: 10.02.01. Ставрополь, 2006.

Гришина, Наталья. Конщепт ВОДА в языковой картине мира: На основе номинативного и метафорического полей русского языка XI-XX вв. Автореф. ...канд. филол. наук: 10.02.01. Саратов, 2002.

Макарець, Юлія. «Концепт 'вода' в українській мовній картині світу (на матеріалі усної народної творчості)». Міжнародний вісник: Культурологія. Філологія. Музикознавство, вип. 1, 2013, с. 106-12, nbuv.gov.ua/UJRN/mvkfm_2013_1(1)_19.

Мініч, Лариса. «Загальнонаціональні концепти душа, життя, любов, вода, земля в поезії М. Вінграновського». Рідний край, № 1, 2010, с. 101-4.

Місінькевич, Олеся. «Концепт "вода" у структурі поетичної картини світу неокласиків (традиційне та індивідуально-авторське)». Наукові записки Національного університету «Острозька академія». Серія: Філологічна, вип. 26, 2012, с. 214-17.

Попова, Зинаида и Стернин Иосиф. Очерки по когнитивной лингвистике, Воронеж, 2001. Словник української мови, за ред. І. К. Білодіда. В 11 т. Київ: Наукова думка, 1970-1980.

Телия, Вероника. «Метафоризация и её роль в создании языковой картины мира». Роль человеческого фактора в языке. Язык и картина мира. Москва: Наука, 1988, c. $173-203$.

\section{References}

Antoniuk, Olena, and Prisovska, Galyna. "Representants of "WATER" concept in T. G. Shevchenko's works". Odessa linguistic journal, iss. 3, 2014, pp. 13-8.

Venzhynovych, Nataliya. "Aktualizatsiia kontseptu voda u frazemakh rosiiskoi ta ukrainskoi mov: linhvokulturolohichnyi aspekt". "Voda" $v$ slavianskoi frazeolohyy $y$ paremyolohyy", vol. 1. Budapest: Tinta Könyvkiadó, 2013, pp. 196-201.

Voitovych, Volodymyr. Ukrainska mifolohiia. Kyiv: Lybid, 2002.

Galdin, Evgenij. Koncept VODA kak polevaja struktura i sposoby ego vyrazhenija $v$ russkom jazyke: Na materiale pojeticheskih tekstov I. A. Brodskogo. PhD Thesis Abstract. Stavropol', 2006.

Grishina, Natal'ja. Koncept VODA $v$ jazykovoj kartine mira: Na osnove nominativnogo $i$ metaforicheskogo polej russkogo jazyka XI-XX vv. PhD Thesis Abstract. Saratov, 2002.

Makarets, Iuliia. "Concept 'water' in the ukrainian language world image (based on folklore)". International Journal. Culturology. Philology. Musicology, вип. 1, 2013, pp. 106-12.

Minich, Larysa. "Zahalnonatsionalni kontsepty dusha, zhyttia, liubov, voda, zemlia v poezii M. Vinhranovskoho". Ridnyi krai, № 1, 2010, pp. 101-4.

Misinkevych, Olesia. "Kontsept "voda" u strukturi poetychnoi kartyny svitu neoklasykiv (tradytsiine ta indyvidualno-avtorske)". Scientific Notes of Ostroh Academy National University: Philology Series, iss. 26, 2012, pp. 214-17.

Popova, Zinaida и Sternin Iosif. Ocherki po kognitivnoj lingvistike, Voronezh, 2001.

Slovnyk ukrainskoi movy, edited by I. K. Bilodid. 11 vols. Kyiv: Naukova dumka, 1970-1980.

Telija, Veronika. "Metaforizacija i ejo rol' v sozdanii jazykovoj kartiny mira". Rol' chelovecheskogo faktora v jazyke. Jazyk i kartina mira. Moskva: Nauka, 1988, pp. 173203. 